\title{
Resultados del programa de prevención escolar Unplugged sobre el uso del tabaco en la República Checa
}

\section{The Effect of the School-Based Unplugged Preventive Intervention on Tobacco Use in the Czech Republic}

\author{
Michal Miovsky; Petr Novak; Lenka Stastna; Roman \\ GabrheLIK; LUCIE JURYSTOVA; JIRI VOPRAVIL
}

Charles University in Prague, First Faculty of Medicine, Department of Addictology of First Faculty of Medicine and General University Hospital

\section{Resumen}

Unplugged es un programa de prevención escolar que se desarrolla en diversos paises europeos, y que cuenta ya con varias evaluaciones. En este caso se pretende medir el impacto de la intervención sobre el consumo de tabaco utilizando las prevalencias de por vida y los últimos 30 días, así como también verificar la duración del efecto mediante un seguimiento. El estudio se diseñó como un ensayo controlado aleatorio. La intervención se basa en el modelo de influencia social integral y se compone de 12 lecciones impartidas a los adolescentes checos en el año académico 20072008. Las prevalencias se calcularon para evaluar las diferencias entre el grupo experimental $(N=914)$ y control $(n=839)$ al cabo de 1, 3, 12, 15 y 24 meses después del final de la intervención. Los datos se recogieron utilizando la versión 2003 del cuestionario del proyecto ESPAD. En cuanto a haber fumado los últimos 30 dias había diferencias significativas entre ambos grupos en favor de la experimental al finalizar la intervención. Dos años después de la finalización de la intervención de los grupos experimentales y de control de 30 dias mostraron tasas de prevalencia de $26,7 \%$ y $33,1 \%$, respectivamente $(p=.01)$. La progresión en la prevalencia durante los últimos 30-dias dentro del grupo experimental fue significativamente más lenta que entre el grupo de control durante el periodo medido. Las diferencias en las tasas de prevalencia de vida no fueron sin embargo significativas. Por tanto la implementación del programa Unplugged resultó significativamente positiva en cuanto al consumo de tabaco entre los adolescentes checos.

Palabras clave: adolescencia, prevención escolar, ensayo controlado aleatorio, tabaco, República Checa.

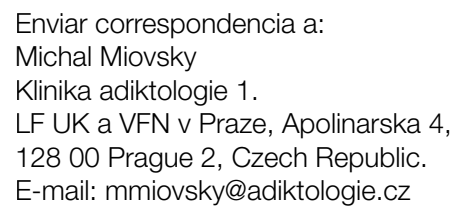

\section{Abstract}

Unplugged is a school prevention programme widely implemtend in Europe, with some positive evaluations. This research aims to measure the impact of this program on tobacco use by means of the lifetime and last-30-day tobacco use prevalence indicators and verify the duration of the intervention's measurable effect over time. The study was designed as a randomised controlled prevention trial. The intervention is based on the Comprehensive Social Influence model and consists of 12 lessons delivered to Czech adolescents in the 2007-2008 academic year. The prevalence indicators were calculated to assess the differences between the experimental $(N=914)$ and control $(N=839)$ groups on each outcome 1, 3, 12, 15, and 24 months after the end of the intervention. Data were collected using the 2003 version of the ESPAD questionnaire. As regards the 30-day smoking prevalence indicator, the tests performed after the completion of the intervention showed statistically significant differences between both groups in favour of the experimental one. Two years after the completion of the intervention the experimental and control groups showed 30-day prevalence rates of $26.7 \%$ and $33.1 \%$, respectively ( $p$ $=.01$ ). The progression of smoking in the 30 -day prevalence among the experimental group was significantly slower than that among the control group over the period of time. The differences in the lifetime prevalence rates were not statistically significant. The implementation of Unplugged resulted in a statistically significant measurable positive effect on tobacco use in Czech adolescents.

Key words: adolescent, school prevention, randomised controlled trial, tobacco use, Czech Republic. 
S chool-based prevention is one of the most suitable strategies for addressing the issue of substance use (UNICRI, 2003) and other risk behaviours in adolescents. Risk behaviour patterns (Jessor, Turbin \& Costa, 1998; Jessor et al., 2003) are referred to as a set of phenomena of which the existence and consequences may be subjected to scientific investigation and controlled by a range of preventive interventions (Miovsky, Skacelova, Zapletalova \& Novak, 2010). The use of tobacco and that of illegal addictive substances share a number of common determinants and show a similar potential for the development of dependency (McLeIlan, Lewis, 0'Brien \& Kleber, 2000). It is one of the major causes of preventable premature deaths and serious health problems (Jha \& Chaloupka, 2000). According to the World Health Organisation (WHO), tobacco use is responsible for 5 million deaths annually worldwide, and the number is expected to rise to 8 million by 2030 (WHO, 2008).

The 2007 ESPAD (European School Survey Project on Alcohol and Other Drugs) survey (Hibell et al., 2009) indicated that the prevalence of tobacco smoking in adolescence was $58 \%$ in the respondents' lifetimes and $29 \%$ in the last 30 days. In addition, a total of $2 \%$ reported having smoked at least a pack of cigarettes on a daily basis in the last 30 days. The highest prevalence rates of smoking in the last 30 days were recorded in the countries of Central and Eastern Europe (Austria 45\%, Czech Republic 41\%, Latvia 41\%, and Bulgaria $40 \%$ ). In these countries, too, respondents are more likely to report that cigarettes are easy to obtain. On a national level, the high prevalence of smoking in the last 30 days is also associated with the early onset of smoking (at the age of 13 or earlier). In particular, daily smoking at an early age is common in the Czech Republic, Estonia, Latvia, and Slovakia (a prevalence of approximately 13\%). Some authors (Best et al., 2000; Vega, 2005) noted a positive correlation between the use of tobacco and other illegal substances. This phenomenon has also been documented in the Czech setting (Csemy, Lejckova \& Sadilek, 2007; Csemy \& Nespor, 2002).

The worrying situation in the Czech Republic was pointed out by the authors of the research carried out from 2002 to 2007 (Sovinova, Csemy, Warren, Lee \& Lea, 2008), showing that the lifetime prevalence of tobacco smoking among 13-15-year-olds reached 70\%. No significant differences between boys and girls were identified. However, one third of the male respondents reported having smoked their first cigarette before they were ten years old (Sovinova et al., 2008).

Numerous metaanalyses and comparative studies of the effectiveness of school-based prevention suggest that smoking prevention interventions (Flay, 2009; Skara \& Sussman, 2003; Sussman, 2002; Wiehe, Garrison, Christakis, Ebel \& Rivara, 2005), as well as school-based interventions focusing on drug prevention in general (e.g. Tobler et al., 2000), vary dramatically in their level of quality and effectiveness. The majority of the evidence-based school-based tobacco prevention interventions (including any of their components involving harm reduction and risk reduction strategies) were developed outside the European continent (e.g. Peterson, Kealey, Mann, Marek \& Sarason, 2000) and, therefore, rely on different cultural and social settings (Adamkova, Jurystova,
Gabrhelik, Miovska \& Miovsky, 2009). Most of the projects with evidence-based effectiveness that have been evaluated are country-specific. Thus, their cross-national transferability, including the process of their adaptation and the testing of their effectiveness in new settings, may be a significant issue to consider in the future. The countries that already have such interventions available include Germany (mean age 11.4 years) (Hanewinkel \& Asshauer, 2004), Sweden (age 13-15 years) (Nilsson, Stenlund, Weinehall, Bergström \& Janlert, 2009), the Netherlands (mean age 13 years) (Crone et al., 2003), and the United Kingdom (age 12-13 years) (Campbell et al., 2008). Van der Kreeft et al. (2009) note that, until recently, there had been a really low number of programmes implemented in the EU. Examples of interventions pursuing an integrated approach to the prevention of smoking in Europe include ESFA (European Smoking Prevention Framework Approach) (mean age 13.3 years) (de Vries et al., 2006) or the Smoke-free Class competition implemented in several EU countries. In terms of the Czech Republic, Miovsky, Stastna, Gabrhelik \& Jurystova (2011) published an overview of evaluations of preventive interventions that had been carried out in the past 20 years.

The basic concept of EU-Dap (European Drug Addiction Prevention trial), a study focusing on the prevention of substance use, came into existence approximately ten years ago. The project produced the Unplugged prevention programe, which was delivered to approximately 7 thousand pupils in seven EU countries (Italy, Spain, Sweden, Belgium, Greece, Austria, and Germany). The results of an evaluation study showed the effectiveness of the intervention among the target population of children aged 12-14 (e.g. Faggiano, Richardson, Bohrn \& Galanti, 2007; Faggiano et al., 2008). As a follow-up project, EU-Dap 2 (Implementation of European Drug Addiction Prevention trial at the population level) was launched in order to confirm the effectiveness of the project. The Czech Republic and Poland joined the EU-Dap 2 project (Adamkova et al., 2009) but too late to be included in the EUDAP prevention trial. Therefore, a randomised controlled trial to study the effect of the Unplugged intervention in the Czech school population was conducted independently of the multinational EU-Dap 2 project.

The key objective of this study was to evaluate the effectiveness of the Czech adaptation of the Unplugged intervention in the Czech school settings. Specifically, we tested: a) the effect of Unplugged on the lifetime prevalence of tobacco use, b) the effect of Unplugged on the last-30day prevalence of tobacco use, and c) the duration of the effect achieved over time (at follow-ups).

\section{Methods}

\section{The Unplugged intervention}

The Unplugged intervention comprises twelve 45-minute lessons for pupils aged 11-14 years. In addition to its preventive effect, the intervention also seeks to divert children from their already-existing patterns of risk behaviour 
(including experimenting and regular use). The curriculum is based on a comprehensive approach that takes into account various social influences. Following this "comprehensive social influence approach" theory (Sussman et al., 2004), Unplugged lessons focus on the development of personal and social skills and the perception of social norms. It is a multifaceted methodology built on a combination of preventive methods, such as those focusing on the development of interpersonal and intrapersonal skills and correction of false normative beliefs and attitudes (Thomas \& Perera, 2006). The comprehensive nature of the intervention should boost the effectiveness of the intervention (Flay, 2009; Josendal, Aaro \& Bergh, 1998; Josendal, Aaro, Torsheim \& Rasbash, 2005; Tobler et al., 2000). Special emphasis is placed on the adjustment of normative beliefs about the use and acceptance of addictive substances and the use of such substances (Faggiano et al., 2010). Effective prevention should result in children finding risk behaviour neither a desirable nor neutral social norm (Burkhart, 2011). More information on the complete methodology and theoretical background of Unplugged is provided in Van der Kreeft et al. (2009).

The implementation and delivery of Unplugged took place in the 2007-2008 academic year. It was performed by school prevention workers who had completed extensive training. The intervention was guided and supervised by the so-called regional prevention coordinators (mostly recruited from the staff of local NGOs) throughout the intervention. This support provided by regional prevention coordinators was essential for the successful implementation of the intervention (Jurystova, Gabrhelik \& Miovsky, 2009). In addition, the evaluation of the intervention implementation process was used to design a new model for the coordination and control of the quality of the prevention intervention at the regional level (Jurystovaet al., 2009; Jurystova \& Miovsky, 2010).

\section{Study design and sample description}

A prospective, randomised controlled prevention trial was conducted to study the effect of the Unplugged school-based universal prevention intervention; it targeted sixth-grade schoolchildren in the Czech Republic. The baseline testing was conducted in September 2007 and the intervention took place during the 2007-2008 school year. Five follow-ups were conducted, one at the end and one at the beginning of each school year (6/2008, 9/2008, 6/2009, 9/2009, 6/2010; Gabrhelik et al., 2012). Prior to randomisation of the schools to the control and intervention arms, stratified random sampling was used to select eligible basic schools from three regions of the Czech Republic. Each of the study arms consisted of 40 randomly selected schools. Five schools (6.3\%) from the control group dropped out before the baseline survey was administered, but too late to be replaced. A total of 1874 sixth-graders (mean age of 11.8 years; males accounting for 50.8\%; 1022 experimental, 852 control; $69.3 \%$ assessed their family income level as moderate) completed the baseline testing. Data were collected from 914 students in the experimental arm and 839 controls in the final follow-up, accounting for $89.43 \%$ and $98.5 \%$ of the initial sample, respectively. Differences in the number of participants at each follow-up were due to temporary absences from school (Gabrhelik et al., 2012). Race and ethnicity were not assessed as a result of their lack of substantive importance in the Czech population and general underreporting by participants (Miovska, 2005). One additional school from the control group was excluded because of high levels of missing data at the baseline. Written parental consent for all eligible children was obtained prior to their participation in the study. The study was approved by the Ethics Committee of the General University Hospital in Prague.

A Czech version (Csemy et al., 2007) of the 2003 ESPAD (Hibell et al., 2009) questionnaire was used to collect the demographic and outcome data throughout the study. The standardised questionnaire covered areas of licit and illicit drug use in student populations (lifetime and last-30-day prevalence). Specific variables indicating the individual prevalence rates of tobacco use were examined for any statistically significant differences between the groups (Pearson Chi-Square). The data were analysed and processed using the SPSS statistical software. The output variables pertaining to both last-30-day and lifetime use prevalence rates were analysed on a dichotomous basis $(1=$ Yes; $0=\mathrm{No})$. Questions inquiring about the lifetime prevalence of tobacco smoking and tobacco use in the last 30 days were selected from the questionnaire. Reflecting the present status of use, the prevalence of smoking in the last 30 days is considered a significant predictor of substance use in the future (Ellickson, Hays \& Bell, 1992).

\section{Results}

Almost $70 \%$ of all the respondents (sixth testing round, eighth grade of basic school) had smoked a cigarette in their lifetime. The results of the testing were not statistically significant; only the results of the fourth round of testing showed interesting differences between the experimental and control groups in the lifetime prevalence of smoking (Fig. 1). One year after the completion of the intervention, the experimental group showed a 57.5\% lifetime prevalence of smoking, while in the control group, $61.8 \%$ of the students had smoked in the past year.

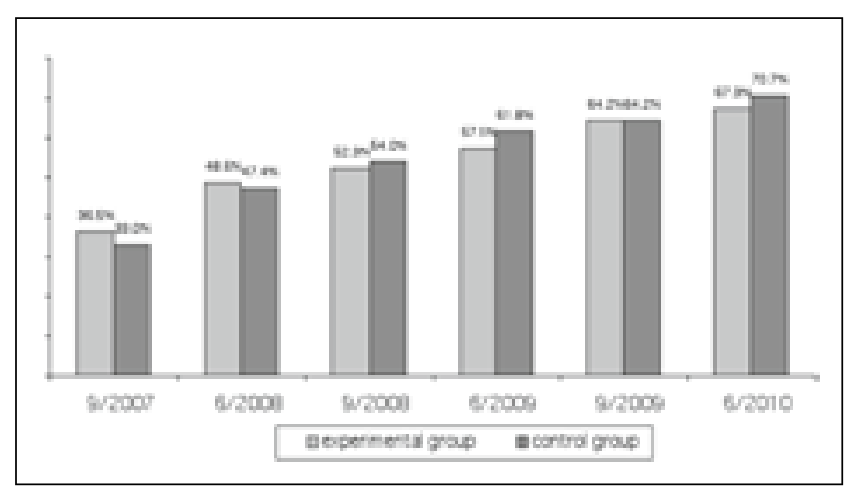

Figure 1. Lifetime prevalence of tobacco smoking. 
The respondents from the experimental sample showed higher lifetime prevalence rates of smoking in the baseline testing and immediately after the intervention. In other testing rounds, the respondents from the control group reported lifetime experience of smoking cigarettes more frequently, with the exception of the beginning of the 20092010 academic year, when the prevalence rates showed equal levels, probably as a result of experimenting during the holidays.

Prior to the start of the intervention (first testing round), the respondents from the experimental group were more likely to have smoked cigarettes in the last 30 days (Fig. 2) than the ones in the control group $(10.1 \%$ and $7.5 \%$ in the experimental and control groups, respectively). Two years after the intervention almost $30 \%$ of all the respondents had smoked cigarettes in the last 30 days (sixth testing round, eighth grade).

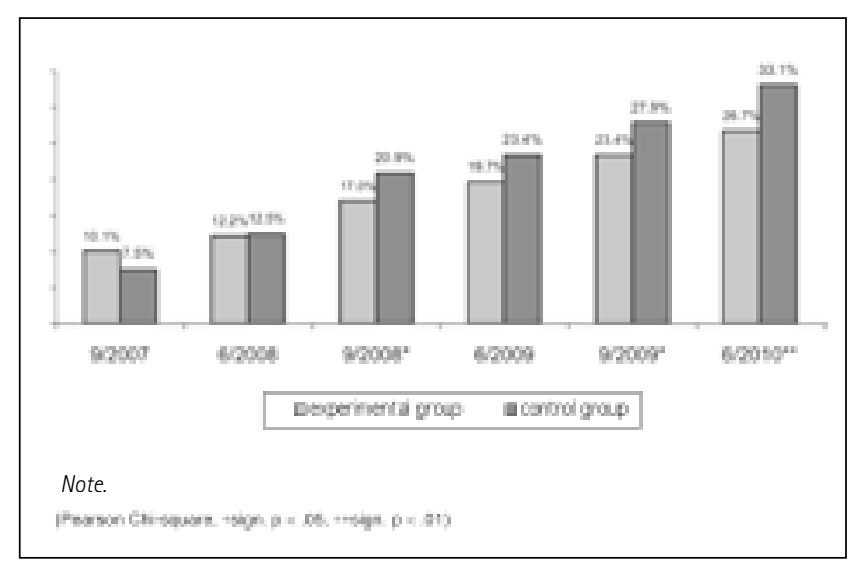

Figure 2. 30-day prevalence of tobacco smoking.

The last-30-days smoking prevalence indicator recorded statistically significant differences between the experimental and control groups immediately after the completion of the intervention. Three months after the intervention the respondents from the control group were statistically significantly more likely to have smoked cigarettes in the last 30 days (20.9\%) in comparison to the experimental group $(17.0 \%)(p=.047 ;$ Pearson Chi-Square $=3.933 ; d f=1)$. One year after the intervention the last-30-day prevalence of smoking cigarettes was $19.7 \%$ among the experimental group, while in the control group $23.4 \%$ of the students had smoked cigarettes in the last 30 days. Fifteen months after the completion of the intervention the respondents from the control group were statistically significantly more likely to have smoked cigarettes in the last 30 days (27.9\%) than the ones in the experimental group $(23.4 \%)$ ( $p=.040$; Pearson Chi-Square $=4.216$; $d f=$ 1). Two years after the intervention the positive effect of the intervention was even more pronounced. Smoking in the last 30 days was recorded among $26.7 \%$ of the experimental group members, while $33.1 \%$ of the students in the control group had smoked cigarettes in the last 30 days ( $p=.006$; Pearson ChiSquare $=7.498 ; \mathrm{df}=1$ ).

Although the increase in the prevalence of smoking cigarettes in the last 30 days in the experimental group was significantly slower than that in the control group, both groups showed a rising tendency. However, an increase in the incidence of smoking with increasing age is a commonly observed phenomenon in early adolescence which it is impossible to fully prevent (Faggiano et al., 2010).

\section{Discussion}

We found statistically significant differences between the experimental group (26.7\%) and the control group (33.1\%) in the last-30-day prevalence rates of cigarette smoking two years after the end of the intervention $(p=.01)$. The progression to increased smoking among the experimental group in the last 30 days was significantly slower than that among the control group over the period of time. The differences in the lifetime prevalence rates of cigarette smoking were not statistically significant.

Tobacco smoking is one of the main causes of premature deaths and serious health problems in Europe and shares a number of common determinants with illegal addictive substances (McLellan et al., 2000, Csemy et al., 2007). However, this risk behaviour may be curbed to a certain degree by effective school-based prevention, although it has been shown that the potential of the Unplugged intervention, in particular, is somewhat limited in this respect. The long-term effects of the Unplugged intervention on the initiation of tobacco use were small, while clear differences have been found for its influence on recent smoking. Over two thirds of students in Czech basic schools had experienced smoking cigarettes by the end of the eighth grade. The respondents from the experimental sample showed a higher lifetime smoking rate during the baseline testing prior to the intervention. While the other rounds of testing recorded a reversal of this trend, these results cannot be fully generalised, as the differences found between the experimental and control groups as regards the lifetime prevalence of smoking were not statistically significant. As far as the prevalence of smoking in the last 30 days is concerned, statistically significant differences between the experimental and control groups were identified in followup testing carried out immediately after the intervention. Statistically significant differences in regular tobacco use were still observed two years after the intervention had been completed, and it was proved that the increase in the prevalence of smoking in the last 30 days was much slower in the experimental group. While the effectiveness of the Unplugged intervention in relation to tobacco use was demonstrated in the Czech Republic, the results indicate that the effect is not very strong. The question is, therefore, whether the positive outcomes of the Unplugged intervention might be reinforced by the application of a suitable booster component addressing the issue of the prevention of tobacco use.

Our results of the evaluation of the school-based Unplugged programme do not fully correspond with those found in the EU-Dap project (Faggiano et al., 2010). The original EU-Dap study looking into the impact of this project 
provided no evidence of statistically significant effectiveness in reducing either regular tobacco use or smoking cigarettes in the last 30 days among the group of students who were exposed to the preventive intervention (Faggiano et al., 2010). In view of the early onset of tobacco use among the population of Czech children, the initial upper age range of 14 years in the EU-Dap study (Faggiano et al., 2008, 2010) was moved down to 12 (i.e. the sixth grade of basic school). It may be assumed that it was this change in the age of the first exposure to the intervention that was able to produce the different results of this intervention study on tobacco use. G. Gomez Cruz et al. (2009) argue that the failure to demonstrate the effectiveness of another school-based smoking prevention intervention, implemented in Spain, was mainly due to the fact that the preventive intervention was introduced too late. While the perceived level of risk of tobacco smoking declines with increasing age, the awareness of the risks associated with the problem use of other drugs rises (e.g. Csemy \& Lejckova, 2005). In addition, the perceived levels of risk often vary according to the individual students' lifestyles (Calafat, Amengual, Farres \& Palmer, 1985; Calafat, Juan \& Duch, 2009). Epstein, Botvin, Diaz, Toth \& Schinke (1995) suggested that the underestimation of risks related to substance use may be due to a lack of information. The media are a major provider of information about addictive substances (Wakefield, Flay, Nichter \& Giovino, 2003), although their coverage is often distorted and tends to resort to the tabloidisation of the issue (Novak, Miovsky \& Stastna, 2009; Novak, Miovsky \& Stastna, 2010). Young people's attitudes to substance use are greatly influenced by the advertising industry (Montes-Santiago \& Castro-Rial, 2009). While it may be impossible to fully prevent tobacco use among all adolescents, the very delay of the onset of smoking until a higher age has many benefits, including a lower incidence of cancer and a better prognosis in terms of ceasing smoking in adulthood (Jit, Aveyard, Barton \& Meads, 2010) or changes in adolescent brain (e.g. Lubman, Yücel \& Hall, 2007).

Another possible explanation of the positive results of our evaluation study may be the fact that, as shown by our survey, only a few preventive interventions are being delivered in Czech schools (Adamkova et al., 2009). On one hand, this finding is very positive in terms of the methodological "purity" of our study; neither during the intervention nor during further follow-ups after its completion did we come across any intervention whose application could affect the results in any way and bias the comparison of both groups. On the other hand, it is a matter of concern that the Unplugged intervention is thus one of the first specific interventions to be implemented in Czech schools on a large scale. This, too, may have caused the outcomes to be so positive, even when compared to other countries. Simply speaking, the Unplugged intervention may have been effective because no other intervention based on the $\mathrm{SCl}$ (Comprehensive Social Influence) model, which is widespread in other countries, e.g. Sweden (Faggiano et al., 2008; Sussman et al., 2004), has been delivered in the schools involved in the project.
While preventive interventions may significantly reduce the health risks associated with the use of addictive substances, they may also generate a totally opposite effect by resulting in a higher level of drug use as a result of an inefficient prevention strategy (the use of misinformation as a scare tactic or failure to provide comprehensive information). It is therefore essential that each schoolbased drug prevention intervention is carefully evaluated (Faggiano, 2010; Jimenez-Iglesias, Moreno, Oliva \& Ramos, 2010, Sanchez-Martinez et al., 2010) before dissemination. The evidence-based approach requires the evaluation component to be considered as early as during the designing of a preventive intervention (Flay et al., 2005). It is important to ensure that schools do not succumb to populist efforts advocating various short cuts and inefficient approaches. The DARE programme may be used as an example of such an inefficient and counterproductive project on which a large quantity of resources were wasted (Ennett, Tobler, Ringwalt \& Flewelling, 1994).

The lifetime prevalence of tobacco use serves as important data demonstrating the existence of both the supply of the drug under consideration and demand for it. However, it cannot be interpreted as a reflection of the level of current use, as this can be characterised especially on the basis of regularity and frequency. The indicator of smoking in the last 30 days may be regarded as much more reliable in this respect (Csemy et al., 2007). High 30-day prevalence rates of use during pre-adolescent age are one of the indicators (for example, in combination with a high prevalence of alcohol use) that may predict a higher risk of the further progression of substance use and even the development of addiction later in life (Ellickson et al., 1992; Miovsky, Miovska, Rehan \& Trapkova, 2007).

This study has several weaknesses worth noting. There were five schools that dropped out before the baseline. However, we found no differences between the drop-out schools and those that remained in the study. Further, the loss from the baseline to the final follow-up was $10.67 \%$ of the students in the experimental group and $1.5 \%$ of the students in the control group. This difference is given by combinations of regular absences (e.g. sickness) and, rarely, transfers to another class or school. The difference in the experimental group in the final follow-up period, conducted at the end of the school year, is higher when compared to the controls. Nevertheless, in the previous follow-ups we collected data from nearly $95 \%$ of the adolescents in the experimental group.

\section{Acknowledgements}

We wish to thank the European Drugs Abuse Prevention (EUDap) Study Group led by Fabrizio Faggiano for introducing the Unplugged school-based preventive intervention to the Czech team and project. The authors wish to express their thanks for the grant support (Institutional support from Programme No. PRVOUK-P03/LF1/9; Project No. CZ.1.07/1.3.00/08.0205 ESF OP Education for Competitiveness). 


\section{Conflicts of interest}

All authors declare that they have no conflicts of interest.

\section{References}

Adamkova, T., Jurystova, L., Gabrhelik, R., Miovska, L. \& Miovsky, M. (2009). Primary Prevention in Schools Involved in the EUDAP 2 Project. Adiktologie, 9, 86-94.

Best, D., Rawaf, S., Rowley, J., Floyd, K., Manning V. \& Strang, J. (2000). Drinking and smoking as concurrent predictors of illicit drug use and positive drug attitudes in adolescents. Drug and Alcohol Dependence, 60, 319- 322.

Burkhart, G. (2011). Environmental drug prevention in the EU. Why is it so unpopular? Adicciones, 23, 87-14.

Calafat, A., Juan, M. \& Duch, M. A. (2009). Preventive interventions in nightlife: A review. Adicciones, 21, 387-414.

Calafat, A., Amengual, M., Farres, C. \& Palmer, A. (1985). Life-style and drug use habits among secondary school students. Bulletin on Narcotics, 37, 113-123.

Campbell, R., Starkey, F., Holliday, J., Audrey, S., Bloor, M., ParryLangdon, N., Moore, L. (2008). An informal school-based peer-led intervention for smoking prevention in adolescence (ASSIST): a cluster randomised trial. Lancet, 371, 1595-1602.

Crone, M . R., Reijneveld, S. A., Willemsen, M. C., van Leerdam, F. J., Spruijt, R. D. \& Sing, R. A. (2003). Prevention of smoking in adolescents with lower education: a school-based intervention study. Journal of Epidemiology and Community Health, 57, 675680.

Csemy, L. \& Nespor, K. (2002). Zkušenost s alkoholem, tabákem a marihuanou výrazn zvyšuji riziko experimentovani s heroinem a pervitinem [Having experiences with alcohol, tobacco and marijuana increases the risk of heroin and pervitin experiments]. Česká a slovenská Psychiatrie, 98, 358-359.

Csemy, L. \& Lejckova, P. (2005). Risk perception and attitudes of young people towards drug use. Adiktologie, 5, 35-44.

Csemy, L., Lejckova, P. \& Sadilek, P. (2007). Substance Use Among Czech Adolescents: An Overview of Trends in the International Context. Journal of Drug Issues, 37, 119-132.

de Vries, H., Dijk, F., Wetzels, J., Mudde, A., Kremers, S., Ariza, C., Candel, M. (2006). The European Smoking prevention Framework Approach (ESFA): Effects after 24 and 30 months. Health Education Research, 21, 116-132.

Ellickson, P. L., Hays, R. D. \& Bell, R. M. (1992). Stepping through the drug use sequence: longitudinal scalogram analysis of initiation and regular use. Journal of Abnormal Psychology, 101, 441-451.

Ennett, S. T., Tobler, N. S., Ringwalt, C. L. \& Flewelling, R. L. (1994). How effective is Drug Abuse Resistance Education? A meta-analysis of Project DARE outcome evaluations. American Journal of Public Health, 84, 1394-1401.
Epstein, J. A., Botvin, G. J., Diaz, T., Toth, V. \& Schinke, S. P. (1995). Social and personal factors in marijuana use and intentions to use drugs among inner city minority youth. Journal of Developmental and Behavioral Pediatrics, 16, 14-20.

Faggiano, F., Richardson, C., Bohrn, K., Galanti, M. R., the EU-Dap Study Group. (2007). A cluster randomized controlled trial of school-based prevention of tobacco, alcohol and drugs use: the EU-Dap design and study population. Preventive Medicine, 44, 170-173.

Faggiano, F., Galanti, M. R., Bohrn, K., Burkhart, G., Cuomo, L., VignaTaglianti, F.,... the EU-Dap Study Group. (2008). The effectiveness of a school-based substance abuse prevention program: EU-Dap Cluster Randomised Controlled Trial. Preventive Medicine, 47, 537-543.

Faggiano, F. (2010). Prevention of substance abuse: Randomised or observational evaluation is absolutely needed. Adicciones, 22, $11-14$.

Faggiano, F., Vigna-Tglianti, F., Burkhart, G., Bohrn, K., Cuomo, L., Gregori, D.,... the EU-Dap Study Group. (2010). The effectiveness of a school-based substance abuse prevention program: 18-Month follow-up of the EU-Dap cluster randomized controlled trial. Drug and Alcohol Dependence, 108, 56-64.

Flay B. R. (2009). School-based smoking prevention programs with the promise of long-term effects. Tobacco Induced Diseases, 5. doi:10.1186/1617-9625-5-6.

Flay, B. R., Biglan, A., Boruch, R. F., Castro, F. G., Gottfredson, D., Kellam, S., et al. (2005). Standards of evidence: Criteria for efficacy, effectiveness and dissemination. Prevention Science, 6, 151-175.

Gabrhelik, R., Duncan, A., Miovsky, M., Furr-Holden, C.D.M., Stastna, L. \& Jurystova, L. (2012). 'Unplugged': A School-Based Randomized Control Trial to Prevent and Reduce Adolescent Substance Use in the Czech Republic. Drug and Alcohol Dependence. http://dx.doi. org/10.1016/j.drugalcdep.2011.12.010.

Gomez Cruz, G., Barrueco Ferrero, M., Aparicio Coca, I., Maderuelo, J. A. \& Torrecilla Garcia, M. (2009). Program for the prevention of smoking in secondary school students. Archivos De Bronconeumologia, 45, 16-23.

Hanewinkel, R. \& Asshauer, M. (2004). Fifteen-month followup results of a school-based life skills approach to smoking prevention. Health Education Research, 19, 125-137.

Hibell, B., Guttormosson, U., Ahlstrom, S., Balakireva, O., Bjarnasson, T., Kokkevi, A. \& Kraus, L. (2009). The 2007 ESPAD Report: Substance Use Among Students in 35 European Countries. Stockholm: The Swedish Council for Information on Alcohol and Other Drugs.

Jessor, R., Turbin, M. S. \& Costa, F. M. (1998). Protective Factors in Adolescent Health Behavior. Journal of Personality and Social Psychology, 75, 788-800.

Jessor, R., Turbin, M. S., Costa, F. M., Dong, O., Zhang, H. \& Changhai, W. (2003). Adolescent problem behavior in China and the United States: A cross-national study of psychosocial protective factors. Journal of Research on Adolescence, 13, 329-360.

Jha, P. \& Chaloupka, F. J. (2000). Tobacco control in developing countries. Oxford: Oxford University Press. 
Jimenez-Iglesias, A., Moreno, C., Oliva, A. \& Ramos, P. (2010). An approach to the assessment of the effectiveness of a drug use prevention program in secondary education in Andalusia. Adicciones, 22, 253-265.

Jit, M., Aveyard, P., Barton, P. \& Meads, C. A. (2010). Predicting the lifetime benefit of school-based smoking prevention programmes. Addiction, 105, 1109-1116.

Josendal, O., Aaro, L. E., Torsheim, T. \& Rasbash, J. (2005). Evaluation of the school-based smoking-prevention program "BE smokeFREE". Scandinavian Journal of Psychology, 46, 189-199.

Josendal, O., Aaro, L. E. \& Bergh, I. (1998). Effects of a school-based smoking prevention program among subgroups of adolescents. Health Education Research, 13, 215-224.

Jurystova, L., Gabrhelik, R. \& Miovsky, M. (2009). "Unplugged" Primary Prevention Programme - Evaluation of the Implementation Process by School Prevention Workers. Adiktologie, 9, 10-19.

Jurystova, L. \& Miovsky, M. (2010). Vybrané aspekty organizačni a odborné podpory pedagogů pri realizaci metodiky Unplugged ve školách: Výsledky evaluace implementace projektu EUDAP [Selected Aspects of Organisational and Expert Support for Teachers and Other Education Professionals in Delivering the Unplugged Programme in Schools: Findings of the Evaluation of the Implementation of the EUDAP Project]. Adiktologie, 10, 147153.

Lubman, D.I., Yücel, M., Hall, W.D. (2007). Substance use and the adolescent brain: A toxic combination? J Psychopharmacol, 21(8), 792-794.

McLellan, A. T., Lewis, D. C., O'Brien, C. P. \& Kleber, H. D. (2000). Drug dependence, a chronic medical illness: implications for treatment, insurance, and outcomes evaluation. JAMA, 284, 1689-1695.

Miovska, L. (2005). Uzivani drog v narodnich mensinach v CR-Souhrn dostupnych informaci. Drugs in Focus 2. [Drug use among ethnic minorities in the Czech Republic-summary of the available information. Drugs in Focus 2.] Praha: Urad vlady CR.

Miovsky, M., Miovska, L., Rehan, V. \& Trapkova, B. (2007). Substance use in fifth- and seventh-grade basic school pupils: Review of results of quasi-experimental evaluation study. Československá psychologie, 103, 109-118.

Miovsky, M., Stastna, L., Gabrhelik, R. \& Jurystova, L. (2011). Evaluation of the Drug Prevention Interventions in the Czech Republic. Adiktologie, 11, 236-247.

Miovsky, M., Skacelova, L., Zapletalova, J. \& Novak, P. (Eds.) (2010). Primárni prevence rizikového chováni ve školstvi [Primary Prevention of Risk Behaviour within the School System]. Praha: SCAN, Univerzita Karlova v Praze \& Togga.

Montes-Santiago, J. \& Castro-Rial, M. L. (2009). Alcoholism prevention and alcohol advertising investment in Spain: David versus Goliath. Adicciones, 21, 203-206.

Nilsson, M., Stenlund, H., Weinehall, L., Bergström, E. \& Janlert, U. (2009). "I would do anything for my child, even quit tobacco": Bonus effects from an intervention that target adolescent tobacco use. Scandinavian Journal of Psychology, 50, 341-345.
Novak, P., Miovsky, M. \& Stastna, L. (2010). The media portrayal of addictive substances users and its social psychological perspective. Lekársky obzor, 59, 80-84.

Novak, P., Miovsky, M. \& Stastna, L. (2009). The media portrayal of cannabis in relation to criminal activities. Adiktologie, 9, 196-203.

Peterson, A. V., Kealey, K. A., Mann, S. L. Marek, P. M. \& Sarason, I. G. (2000). Hutchinson Smoking Prevention Project: Long-term randomized trial in school-based tobacco use prevention Results on smoking. Journal of the National Cancer Institute, 92, 1979-1991.

Sanchez-Martinez, F., Cardenal, A .A., Gimenez, A. P., Ferrer, M. D., Medina, M. J. L. \& Adell, M. N. (2010). Process evaluation of the school-based cannabis use prevention program "xkpts.com" in adolescents from Barcelona in 2006. Adicciones, 22, 217-226.

Skara S. \& Sussman S. (2003) A review of 25 long-term adolescent tobacco and other drug use prevention program evaluations. Preventive Medicine, 37, 451-474.

Sovinova, H., Csemy, L., Warren, C. W., Lee, J. \& Lea, V.(2008). Changes in tobacco use among 13-15-year-olds in the Czech Republic 2002 and 2007. Cent Eur J Public Health, 16, 199-204.

Sussman, S., Earleywine, M., Wills, T., Cody, C., Biglan, T., Dent, C. W. \& Newcomb, M. D. (2004). The motivation, skills, and decisionmaking model of "drug abuse" prevention. Substance Use \& Misuse, 39, 1971-2016.

Sussman, S. (2002). Effects of sixty-six adolescent tobacco use cessation trials and seventeen prospective studies of self-initiated quitting. Tobacco Induced Diseases, 1, 35-81.

Thomas, R. \& Perera, R. (2006). School-based programmes for preventing smoking. The Cochrane Database of Systematic Reviews (3), doi:10.1002/14651858, Art. No.: CD001293.

Tobler, N. S., Roona, M. R., Ochshorn, P. M., Diana, G., Streke, A. V. \& Stackpole, K. M. (2000). School-based adolescent drug prevention programmes: 1998 meta-analysis. Journal of Primary Prevention, 20, 275-336.

UNICRI. (2003). School-Based Drug Education: a guide for practitioners and the wider community. Vienna: United Nations Office for Drug Control and Crime Prevention.

Van der Kreeft, P., Wiborg, G., Galanti, M. R., Siliquini, R., Bohrn, K., Scatigna, M.,... the EU-Dap Study Group. (2009). Unplugged": a new European school program against substance abuse. Drugs Education Prevention and Policy, 16, 167-181.

Vega, W. A. (2005). Revisiting drug progression: long-range effects of early tobacco use. Addiction, 100, 1358-69.

Wakefield, M., Flay, B., Nichter, M. \& Giovino, G. (2003). Role of the media in influencing trajectories of youth smoking. Addiction, 98 , 79-103.

Wiehe, S. E., Garrison, M. M., Christakis, D. A., Ebel, B. E. \& Rivara, F. P. (2005). A systematic review of school-based smoking prevention trials with long-term follow-up. Journal of Adolescent Health, 36, 162-169.

World Health Organisation. (2008). WHO report on the global tobacco epidemic, 2008. Geneva: WHO. 
